\title{
Giardia intestinalis AND NUTRITIONAL STATUS IN CHILDREN PARTICIPATING IN THE COMPLEMENTARY NUTRITION PROGRAM, ANTIOQUIA, COLOMBIA, MAY TO OCTOBER 2006
}

Jorge H. BOTERO-GARCÉS(1,2,5), Gisela M. GARCÍA-MONTOYA(1,2,5), Dayvin GRISALES-PATIÑO(2,5), Daniel C. AGUIRRE-ACEVEDO(4,5) \& Martha C. ÁLVAREZ-URIBE(3,5)

\begin{abstract}
SUMMARY
Giardia intestinalis infection is prevalent throughout the world and widely distributed in developing countries. In general, children display serious consequences to their state of health, including slow height-weight development; therefore, the main aim of this study was to determine the association between Giardia infection and the nutritional status of children who participate in the program of complementary feeding (Mejoramiento Alimentario y Nutricional de Antioquia (MANA) - Instituto Colombiano de Bienestar Familiar (ICBF)). A cross-sectional study examining the association of giardiasis with nutritional status was conducted. A total of 2035 children aged eight months to six years-old were studied. Data were collected using structured questionnaires, anthropometric measurements and laboratory analysis of blood and stool samples. Analysis of the results showed that $27.6 \%$ of children were infected with $G$. intestinalis, while $8.1 \%$ and $1.9 \%$ were mildly and significantly underweight, respectively, and $14.1 \%$ presented stunting. Giardiasis was statistically identified as a strong predictor of stunting in this study population.
\end{abstract}

KEYWORDS: Giardia; Giardiasis; Nutritional status; Prevalence; Iron deficiency anemia; Children; Colombia.

\section{INTRODUCTION}

Giardia intestinalis is the most frequently reported intestinal parasite worldwide. It can cause acute or chronic diarrhea, contributing to nutritional deficiency, or remain asymptomatic ${ }^{2,9}$. In developed countries it is the leading cause of diarrheal disease outbreaks associated with drinking water ${ }^{21,23,43,44}$.

Children are more frequently infected than adults, particularly those from developing countries and those malnourished ${ }^{7,22}$. In these countries, however, giardiasis is endemic and commonly reported in children aged 2-12 years-old ${ }^{2,51,52}$

Giardiasis is a self-limiting illness and most often, infections are asymptomatic. However, it is common for acute symptomatic individuals to present with diarrhea or clinical manifestations of malabsorption. Malabsorption of fat, D-xylose, vitamin A and vitamin B12 have been reported associated with this infection ${ }^{3,12,34,47}$. Chronic giardiasis in children is generally associated with clinical manifestations of failure to thrive ${ }^{1,9,48,53}$. The association of giardiasis with proteinenergy malnutrition (PEM) and micronutrient deficiency, and more recently with iron deficiency anemia (IDA), has been reported by some researchers ${ }^{1,6,9,26,29,40,42,48}$. Moreover, positive association between giardiasis and PEM has previously been described ${ }^{19}$.

Growth failure is associated with increase morbidity and mortality in children and it is estimated that as many as 182 million children in developing countries are affected ${ }^{45}$. Although the etiology of growth failure is multifactorial, malnutrition and repeated infections in children have been documented as causative agents, among which $G$. intestinalis is a hallmark cause ${ }^{16}$. Diarrhea, poor sanitation, housing and socioeconomic conditions are factors that contribute to the high prevalence of this parasite $e^{2,3,4,10,46,52}$. Moreover, these are nonfood factors that can also be involved in growth failure ${ }^{2,4,5}$. The presence of more than one of these conditions leads to an increased risk of impaired growth and malnutrition ${ }^{46}$.

Growth failure, indicated by stunting, wasting and underweight conditions, can be assessed by anthropometric indices of height-forage (HAZ), weight-for-age (WAZ), and weight-for-height (WHZ). Stunting is a consequence of long-term poor nutritional intake and is the best indicator of growth retardation in children over an extended period, because stunting has been associated with poorer cognition and school achievement in later childhood ${ }^{11}$. Antioquia, Colombia, is a Latin American regional area, called a department, divided into nine subregions, whose numerous sociodemographic, environmental and food factors contribute to nutritional deficiencies, malnutrition and high prevalence of intestinal parasitism in the population.

This study was conducted in the nine subregions located within the department of Antioquia, in order to examine the association between giardiasis and nutritional status among children participating in the complementary nutrition program, MANA-ICBF (Mejoramiento Alimentario y Nutricional de Antioquia, Instituto Colombiano de

\footnotetext{
1. Departamento de Microbiología y Parasitología, Facultad de Medicina.

2. Grupo Interdisciplinario para el Estudio de las Parasitosis Intestinales, Corporación Académica para el Estudio de Patologías tropicales

3. Escuela de Nutrición y Dietética, Grupo de Investigación en Alimentación y Nutrición Humana.

4. Grupo de Investigación de Neurociencias.

5. Universidad de Antioquia, Colombia.

Correspondence to: Jorge H. Botero-Garcés. E-mail: jbotero@ quimbaya.udea.edu.co
} 


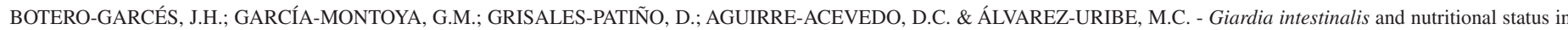
children participating in the complementary nutrition program, Antioquia, Colombia, May to October 2006. Rev. Inst. Med. trop. S. Paulo, 51(3): 155-162, 2009.

Bienestar Familiar), Antioquia, Colombia, an endemic area of intestinal parasitic infections.

\section{MATERIALS AND METHODS}

Study areas and study population: This is part of a cross-sectional study on the relationship between intestinal parasitic infections and childhood nutritional status in children living in nine subregions located within the state of Antioquia, Colombia: Valle de Aburrá, Oriente, Suroeste, Occidente, Norte, Nordeste, Magdalena Medio, Urabá and Bajo Cauca. All children participate in the complementary nutrition program MANA-ICBF. A census population of the families living in these subregions of Antioquia identified 200,000 children aged between eight months and six years-old. Random samples of 125 targeted municipalities were selected for a systematic village held survey conducted between May and October 2006, with a standard error of 5\% and a 95\% confidence interval $(95 \% \mathrm{CI})$. Thus, 2,754 children between these ages were included if their parents or other adult with legal custody of the child agreed to provide written informed consent. Of the 2,508 children studied, 2,035 $(81.14 \%)$ children delivered stool specimens for examination and analyses to determine the association between giardiasis and nutritional status were based on these children.

Structured questionnaire: Each of the children was given a code and personal data were entered into the database. Using a standardized questionnaire, the parents or adults were interviewed directly concerning the children's personal information, as well as socioeconomic status, home and environmental factors that could be associated with the transmission of intestinal agents and influence child growth patterns. Date of birth and birth weight were obtained from birth certificates, immunization status was obtained from each child's medical records and individual state of health was determined by medical evaluation.

Anthropometry: The study investigators met with the primary caregivers and the children in local hospitals. All children underwent anthropometric measurements by a trained assistant, as follows: the children were weighed without shoes using a portable digital electronic balance with a capacity of $0-150 \pm 0.1 \mathrm{~kg}$ (AND Fv-150 KA1, A\&D Co, Ltd, Japan) and height was measured using a Holtain stadiometer, $205 \pm 0.1 \mathrm{~cm}$ (Holtain Ltd, UK). Both measurements were performed following standardized procedure ${ }^{20}$. To reduce intraindividual error, weight and height were measured twice and the mean value was used for the analysis. The weight-for-age $Z$-scores were used to denote underweight as an overall indicator for malnutrition, height-for-age $Z$-scores were used as an indicator for stunting (chronic malnutrition) and weight-for-height $Z$-scores were used as an indicator for wasting (acute malnutrition). The $Z$-scores were calculated based on the median values of the National Center for Health Statistics (NCHS) Reference Population, USA, or the World Health Organization International Reference Population $^{31,32}$. In this study, children who obtained Z-scores below -2 standard deviations (SD) of the NCHS Reference or WHOIR Population median were considered significantly malnourished and children with $Z$-scores between 1 and -2 SD were considered mildly malnourished.

Blood examination: Approximately 2-5 $\mathrm{mL}$ of venous blood was collected from each child, transferred into a plain tube and taken to laboratory for biochemical analysis. The blood was allowed to clot and the tubes were centrifuged at 3,000 rpm for $10 \mathrm{~min}$ to obtain the serum.

Hemoglobin concentration: Hemoglobin concentration was determined by the azide metahemoglobin method in a manual portable photometer HemoCue (HemoCue, Inc. 40 Empire Dr Lake Forest, CA 92630, USA) using controls and standard concentrations. This method has been validated in reference to the cyanmethemoglobin method and for quality control of hemoglobin determination in the field, standard curves were constructed daily. The cutoffs for anemia were: children between one and four years-old, $<11.0 \mathrm{mg} / \mathrm{dL}$ and children up five yearsold $<11.5 \mathrm{mg} / \mathrm{dL}^{55}$. Hemoglobin values were adjusted according to the altitude of villages studied.

Ferritin: Serum ferritin concentrations were analyzed using the reference method, natural chemoluminescence. In this test, acridinium ester reacts by $\mathrm{pH}$ acid-basic shift, with a sensitivity of $10-14 \mathrm{ng} / \mathrm{mL}$. Anemic children (low hemoglobin concentration) with low serum ferritin $(<12 \mu \mathrm{g} / \mathrm{L}$ ) were considered to have iron deficiency anemia (IDA) and children at risk of IDA, ferritin between $12-24 \mu \mathrm{g} / \mathrm{L}^{55}$.

Serum reactive C-protein: The array 360 system nephelometer (Beckman coulter, Inc, Mississauga, Ontario, Canada) was used to determine serum reactive C-protein levels with cutoff at $1.2 \mathrm{mg} / \mathrm{dL}$.

Fecal examination: One fresh stool sample per child was collected into a clean $100 \mathrm{~mL}$ wide mouth screw-cap container and conserved in formalin until laboratory examination. Stool samples were collected from the children on the day the questionnaire was filled out. Samples with water or urine contamination were discarded. Stool samples were evaluated by direct microscopic examination and the Ritchie concentration technique ${ }^{39}$.

Statistical analysis: Statistical analyses of the data were performed using the SPSS program, version 14.0 (SPSS Inc., Chicago, IL, USA). For descriptive data, the rate (percentage) was used to assess disease prevalence. Proportions were compared using the Chi square $\left(\chi^{2}\right)$ test. Univariate and multivariate analyses were used to determine any risk factors. The $Z$-scores for weight-for-age, height-for-age and weightfor-height were derived using the National Committee for Clinical Laboratory Standards, Precision Performance of Clinical Chemistry Devices (Tentative Guideline, $2^{\text {nd }}$ edition; NCCLS publication EP5-T2, Villanova, PA; 1992).

Ethical aspects: This study was approved by the Ethics in Research Committee of the Faculty of Medicine of the University of Antioquia, Colombia, and was supported by the Gobernación de Antioquia, Dirección Seccional de Salud de Antioquia, Project Grant CI148-2005. The caregivers were told that if their child was positive for Giardia, the child would be treated with a dose of metronidazole, according to current treatment recommendations of the Center for Studies of Sensory Impairment, Aging and Metabolism. After explaining the study, informed consent was obtained from those willing to participate.

\section{RESULTS}

Sociodemographic and general characteristics of the children participating in the complementary nutrition program MANA-ICBF, 


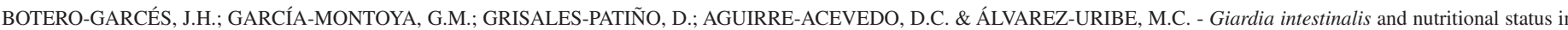
children participating in the complementary nutrition program, Antioquia, Colombia, May to October 2006. Rev. Inst. Med. trop. S. Paulo, 51(3): 155-162, 2009.

Antioquia, Colombia, are shown in Tables 1 and 2. The final number of participants was 2,754 children (1,428 boys; 1,326 girls) aged eight months to six years-old, with a median age of 3.7 years (interquartile range 2.6).

Stool specimens were submitted by 2,035 of the 2,754 (73.9 percent) children selected from the complementary nutrition program MANAICBF. These children did not differ by gender, ethnicity or socioeconomic status (Table 1). The overall prevalence of mildly and significantly underweight children was $8.1 \%$ (95\% CI 6.7-9.6) and 1.9\% (95\% CI 2.2-

Table 1

Sociodemographic characteristics of the household of children participating in the complementary nutrition program MANA-ICBF in Antioquia, Colombia, 2006

\begin{tabular}{lccc}
\hline Characteristic & \multicolumn{2}{c}{ Resident place } & \multirow{2}{*}{ Antioquia } \\
\cline { 2 - 3 } & Urban & Rural & \\
\hline $\mathrm{n}$ & 910 & 1125 & 2035
\end{tabular}

Sisben status$$
1
$$$$
2
$$$$
3
$$

No data

$\begin{array}{ccc}62.8 & 49.7 & 55.7 \\ 32.2 & 46.1 & 39.9 \\ 1.8 & 1.2 & 1.4 \\ 3.2 & 3.0 & 3.0\end{array}$

\section{Mother's education}

Illiterate

Incomplete primary education

Complete primary education

Incomplete High School

Complete High School

Technical School / University

Not filled out

No data

\section{Father's education}

Illiterate

Incomplete primary education

Complete primary education

Incomplete High School

Complete High School

Technical School / University

Not filled out

No data

\section{Family income per/day USD}

\begin{tabular}{lccc}
$<1$ & 83.2 & 93.5 & 88.9 \\
1 to 2 & 13.7 & 6.1 & 9.5 \\
$\geq 3$ & 3.1 & 0.4 & 1.6 \\
\hline
\end{tabular}

$\begin{array}{lll}17.6 & 27.6 \quad 23.1\end{array}$

25.6

21.4

23.1

14.5

$2.9 \quad 0.4$

1.5

0.2

0.3

1.5

1.6
2.6), respectively. The total prevalence of stunting was $14.1 \%(95 \% \mathrm{CI}$ 12.2-15.9).

The prevalence of $G$. intestinalis, other intestinal parasites and multiparasitism is shown in Table 3. It is evident that of the 2,035 children studied, $27.6 \%$ (561) were positive for $G$. intestinalis infection. Overall, boys (27.6\%, CI: 24.91 - 30.39) and girls (27.7\%, CI: 24.82 30.5 ) showed the same prevalence of giardiasis as the entire group of children (Table 4). Prevalence of giardiasis was slightly higher among children in the four to six year-old age group than in younger children,

Table 2

General characteristics of children participating in the complementary nutrition program MANA-ICBF in Antioquia, Colombia

\begin{tabular}{lccc}
\hline Characteristic & \multicolumn{2}{l}{ Place of residence } \\
\cline { 2 - 4 } & Urban & Rural & Total \\
\hline $\mathrm{n}$ & 910 & 1125 & 2035
\end{tabular}

Floor

Bare-earth

$\begin{array}{lcc}14.8 & 27.3 & 21.7 \\ 66.5 & 63.4 & 64.8 \\ 18.4 & 8.7 & 13.0\end{array}$

Crowding

Crowds

26.

Critic crowd

34

27.4

26.8

Fuel for cooking*

Electric power

10.

36.1

35.4

Gas

Wood

84.3

$$
6.3
$$

8.0

\section{Sanitation facilities*}

Piped water inside the dwelling

$\begin{array}{lll}14.8 & 70.1 & 45.4\end{array}$

Garbage dwelling out

73.2

46.3

58.3

Dumps near dwelling

30.1

32.0

31.2

Hold back water near dwelling

17.1

16.7

16.9

Sewage water near dwelling

21.6

17.4

19.3

Sewer

24.2

21.0

22.4

82.0

38.9

58.2

Contaminated water near

27.8

22.1

24.7

dwelling

Household in high risk zone

20.3

20.2

20.2

\section{Excreta disposal facilities}

Latrine

7.0

12.9

10.3

Septic tank

6.4

27.8

18.2

On soil

11.9

25.8

19.6

Toilet bowl

91.8

74.6

82.3

Animals inside dwelling

33.4

60.2

48.2

Animals near dwelling

33.5

39.3

36.7

* Answer not exclusive. 


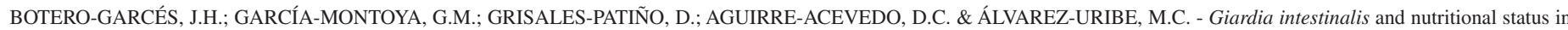
children participating in the complementary nutrition program, Antioquia, Colombia, May to October 2006. Rev. Inst. Med. trop. S. Paulo, 51(3): 155-162, 2009.

but this difference was not statistically significant $\left(\chi^{2}=0.24, p=0.62\right.$; Table 4).

Several sanitation facilities were selected, including water supplies, sewage and excreta disposal (Table 5). Lack of piped water inside the house, contaminated and hold back water near the dwelling, lack of sewerage, defecation in open areas, garbage and dumps near the Table 3

Giardia intestinalis prevalence and other intestinal parasites among children participating in the complementary nutrition program MANA-ICBF, according to age and gender

\begin{tabular}{lccc}
\hline Intestinal parasite & $\mathrm{n}$ & $\%$ & $95 \%$ CI \\
\hline Protozoan & 561 & 27.6 & $(25.6-29.6)$ \\
G. intestinalis & 501 & 24.6 & $(22.7-26.6)$ \\
E. histolytica/dispar & 384 & 18.9 & $(17.2-20.6)$ \\
E. coli & 496 & 24.4 & $(22.5-26.3)$ \\
E. nana & 55 & 2.7 & $(2.06-3.5)$ \\
I. butscklii & 82 & 4 & $(3.2-5.0)$ \\
C. mesneli & 2 & 0.1 & $(0.02-0.4)$ \\
T. hominis & 5 & 0.2 & $(0.1-0.6)$ \\
B. coli & 34 & 1.7 & $(1.2-2.4)$ \\
B. hominis & 123 & 6 & $(5.1-7.2)$ \\
E. hartmani & 15 & 0.7 & $(0.4-1.2)$ \\
C. cayetanensis & 3 & 0.1 & $(0.03-0.4)$ \\
I. belli & & & \\
Helminths & 467 & 22.9 & $(21.1-24.9)$ \\
T. trichiura & 354 & 17.4 & $(15.7-19.1)$ \\
A. lumbricoides & 120 & 5.9 & $(4.9-7.03)$ \\
Uncinarias & 22 & 1.1 & $(0.7-1.7)$ \\
S. stercoralis & 17 & 0.8 & $(0.5-1.4)$ \\
H. nana & 4 & 0.2 & $(0.06-0.5)$ \\
H. diminuta & 566 & 27.8 & $(25.9-29.8)$ \\
\hline Multiparasitism & & &
\end{tabular}

Table 4

Prevalence of $G$. intestinalis among children participating in the complementary nutrition program MANA-ICBF, according to age and gender

\begin{tabular}{lcccc}
\hline & & \multicolumn{3}{c}{ G. intestinalis infection } \\
\cline { 3 - 5 } & & \multicolumn{3}{c}{ Yes } \\
\cline { 3 - 5 } & Total & $\mathbf{n}$ & \% & 95\% CI \\
\hline Age (years) & & & & \\
$\leq 3$ & 1172 & 319 & 27.2 & $(24.71-29.88)$ \\
4 to 6 & 848 & 238 & 28.1 & $(25.09-31.24)$ \\
$\geq 6$ & 15 & 4 & 26.7 & $(8.91-55.17)$ \\
Gender & & & & \\
Male & 1052 & 290 & 27.6 & $(24.91-30.39)$ \\
Female & 983 & 271 & 27.6 & $(24.82-30.50)$ \\
\hline
\end{tabular}

dwelling were all significantly associated with $G$. intestinalis-positive stools (Table 5).

Statistical analysis did not identify giardiasis as a predictor of being underweight or wasting in this study population; however, a statistically significant association between this parasitoses and stunting was observed compared to the growth of normally nourish children $\left(\chi^{2}=13.3, p=\right.$ 0.0003; Table 6). No association between giardiasis and iron deficiency anemia was determined $\left(\chi^{2}=2.8, p=0.094\right)$.

\section{DISCUSSION}

The present study observed a slightly higher prevalence of giardiasis among children participating in the complementary nutrition program MANA-ICBF compared with two previous studies conducted by the Colombian National Institute of Health, which reported also that $G$. intestinalis was the most prevalent intestinal parasite. In 1965, the prevalence was $9.4 \%$ and in the 1980 survey, the rate was $21.4 \%$. These prevalences were reported for children in the five to 14 year-old age group living in the central region of Colombia, where the department of Antioquia is located. In both studies, the diagnostic methods were the same as those used in the present study, microscopic stool examination and the rates were estimated from the evaluation of only one sample ${ }^{13}$. However, Giardia prevalence in this study was lower than that reported among children living in post-earthquake camps in Armenia, Colombia (60.4\%), who lived in temporary housing under poor hygiene-sanitary conditions ${ }^{27}$.

The prevalence of Giardia in the present study was high compared with recent studies conducted in rural areas of different countries: $15.9 \%$ in Nicaragua ${ }^{51}, 9.9 \%$ and $19.6 \%$ in Brazil ${ }^{17,33}, 18.5 \%$ among the Ecuadorian highland community ${ }^{37}, 4.7 \%$ in Peru ${ }^{24}, 3.7 \%$ in Argentina ${ }^{28}$, $13.7 \%$ in $\mathrm{Nepal}^{56}$ and $2.2 \%$ in two provinces of Thailand ${ }^{54}$. In contrast, the prevalence of Giardia was higher among preschool children from El Alto, La Paz, Bolivia $(38.4 \%)^{38}$, and among aboriginal groups in Australia $(36.6 \%)^{36}$.

Although, the prevalence of Giardia according to age group was not statistically significant, a slightly higher prevalence was observed among children aged four to six years-old than among zero to three years-old and over six years-old. This could indicate that infection transmission occurs during intermediate childhood, perhaps when children normally play in very close contact. This result was in agreement with a study of a rural community in Malaysia, which reported higher association among two to six year-old children ${ }^{3}$.

Analysis determined that a higher prevalence of Giardia was associated with a lack of piped water inside the house, contaminated and hold back water near the dwelling, lack of sewerage, defecation in open areas, garbage and dumps near the dwelling and an illiterate child primary caregiver, indicating that these factors favored the dissemination of Giardia intestinalis among the children of this study. Giardiasis was most prevalent in children with poor water supplies, principally those lacking piped water, although it is known that Giardia survives in chlorinated water ${ }^{14}$. To protect against transmission, all drinking water should receive chemical pretreatment, preferably with sedimentation and filtration in addition to disinfection ${ }^{25}$, and municipal water should be supplied with a concentration of less than 0.7 to 70 cysts per 100 liters $^{40}$; however in the department of Antioquia, this level of control is not achieved. 


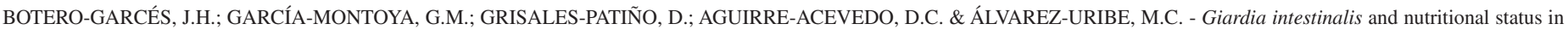
children participating in the complementary nutrition program, Antioquia, Colombia, May to October 2006. Rev. Inst. Med. trop. S. Paulo, 51(3): 155-162, 2009.

Table 5

Selected risk factors associated with $G$. intestinalis infection among children participating in the complementary nutrition program MANA-ICBF in Antioquia, Colombia

\begin{tabular}{|c|c|c|c|c|c|c|c|c|c|}
\hline \multirow{3}{*}{ Risk factor } & \multicolumn{9}{|c|}{ Giardia intestinalis infection } \\
\hline & \multicolumn{2}{|c|}{ Positive } & \multicolumn{2}{|c|}{ Negative } & \multirow[b]{2}{*}{$\chi^{2}$} & \multicolumn{3}{|c|}{ value } & \multirow{2}{*}{$\begin{array}{c}95 \% \text { CI OR } \\
(\mathrm{Li}-\mathrm{Ls})\end{array}$} \\
\hline & No & $\%$ & No & $\%$ & & $\mathrm{gl}$ & $p$ & OR & \\
\hline Piped water inside the dwelling & & & & & 10.4 & 1 & 0.001 & 0.7 & $(0.6-0.9)$ \\
\hline Yes & 426 & 26.2 & 1202 & 73.8 & & & & & \\
\hline No & 134 & 33.3 & 269 & 66.7 & & & & & \\
\hline Defecation in Open Area & & & & & 5.3 & 1 & 0.021 & 1.3 & $(1-1.7)$ \\
\hline Yes & 128 & 32.2 & 270 & 67.8 & & & & & \\
\hline No & 431 & 26.4 & 1201 & 73.6 & & & & & \\
\hline Garbage dwelling out & & & & & 7.7 & 1 & 0.006 & 1.3 & $(1.1-1.6)$ \\
\hline Yes & 200 & 31.5 & 434 & 68.5 & & & & & \\
\hline No & 357 & 25.6 & 1036 & 74.4 & & & & & \\
\hline Dumps near dwelling & & & & & 5.3 & 1 & 0.021 & 1.3 & $(1-1.7)$ \\
\hline Yes & 112 & 32.6 & 232 & 67.4 & & & & & \\
\hline No & 445 & 26.5 & 1237 & 73.5 & & & & & \\
\hline Contaminated water near dwelling & & & & & 11.0 & 1 & 0.001 & 1.4 & $(1.2-1.8)$ \\
\hline Yes & 167 & 33.3 & 335 & 66.7 & & & & & \\
\hline No & 392 & 25.8 & 1137 & 74.4 & & & & & \\
\hline Hold back water near dwelling & & & & & 4.9 & 1 & 0.026 & 1.4 & $(0.9-2.1)$ \\
\hline Yes & 126 & 32.1 & 267 & 67.9 & & & & & \\
\hline No & 431 & 26.5 & 1197 & 73.5 & & & & & \\
\hline
\end{tabular}

Table 6

Relationship between $G$. intestinalis and the nutritional status of children participating in the complementary nutrition program MANA-ICBF in Antioquia, Colombia

\begin{tabular}{|c|c|c|c|c|c|c|c|c|c|}
\hline \multirow{3}{*}{ Nutritional status } & \multicolumn{9}{|c|}{ Giardia intestinalis infection } \\
\hline & \multicolumn{2}{|c|}{ Positive } & \multicolumn{2}{|c|}{ Negative } & \multirow[b]{2}{*}{$\chi^{2}$} & \multicolumn{3}{|c|}{ value } & \multirow{2}{*}{$\begin{array}{c}95 \% \text { CI OR } \\
(\mathrm{Li}-\mathrm{Ls})\end{array}$} \\
\hline & No & $\%$ & No & $\%$ & & $\mathrm{gl}$ & $p$ & OR & \\
\hline Stunting & & & & & 13.3 & 1 & 0.000 & 1.6 & $(1.2-2.1)$ \\
\hline Yes & 106 & 19.1 & 186 & 12.7 & & & & & \\
\hline No & 448 & 80.9 & 1275 & 87.3 & & & & & \\
\hline Underweight & & & & & 0.0 & 1 & 0.885 & 1.0 & $(0.7-1.5)$ \\
\hline Yes & 42 & 7.6 & 108 & 19.5 & & & & & \\
\hline No & 512 & 92.4 & 1353 & 20.5 & & & & & \\
\hline Wasting & & & & & 0.4 & 1 & 0.537 & 0.8 & $(0.3-1.8)$ \\
\hline Yes & 7 & 1.3 & 24 & 4.3 & & & & & \\
\hline No & 547 & 98.7 & 1437 & 95.7 & & & & & \\
\hline Iron Deficiency Anemia & & & & & 2.8 & 1 & 0.094 & & \\
\hline Yes & 38 & 6.8 & 72 & 5.1 & & & & & \\
\hline No & 523 & 93.2 & 1400 & 94.9 & & & & & \\
\hline
\end{tabular}




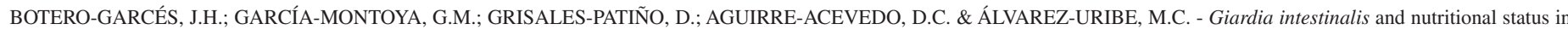
children participating in the complementary nutrition program, Antioquia, Colombia, May to October 2006. Rev. Inst. Med. trop. S. Paulo, 51(3): 155-162, 2009.

Due to the multiple physical, biological, social and cultural problems that occur in developing countries, including economic constraints and political priorities, undernutrition is rarely exclusively due to dietary inadequacy alone in such populations ${ }^{35}$. Nevertheless, it is still controversial whether intestinal parasitic infection can influence the nutritional status of children, because protein energy malnutrition and intestinal parasitic infection are common problems in populations characterized by low socioeconomic status and low levels of public health sanitation, like Colombia ${ }^{45}$. Some longitudinal studies have shown an association between Giardia infection and undernutrition, while others have not verified the same results. A study in Brazil reported that children with symptomatic infections presented significantly lower weight-for-age and height-for-age ${ }^{9}$ and a study in Malaysia showed that children with giardiasis were significantly underweight and wasting compared to those without this parasitoses ${ }^{3}$. In contrast, a cross-sectional study in Guatemala involving children with asymptomatic Giardia infection reported that only the literacy status of the primary caregiver and the number of children in the household was related to the prediction of stunting among the children participating in the study ${ }^{46}$.

The present study determined that Giardia infection was not a predictor of being underweight or wasting; however, this infection showed a strong association with stunting, which suggests that the development of a Giardia chronic carrier state may occur at a young age. Given the high prevalence of asymptomatic infection $(78.8 \%)$ in the present study population, this state could lead to linear grow retardation (stunting) among infected children. Perhaps the undernourished children progressively adapt until maximum adaptation is reached even in the presence of Giardia infection. Thus, children may appear to have normal weight-for-age (underweight) and weight-for-height (wasting), but, in reality, they have very low stature that only becomes visible at a later stage of development. This situation has been referred to as "homeorhesis" and it is probable that the high prevalence of Giardia infection among the children participating in the complementary nutrition program MANA-ICBF and/or the artificial distinction between infected and uninfected individuals could have hidden any statistical association between Giardia infection, underweight and wasting and uninfected and infected children ${ }^{49,50}$.

The present study observed no association between iron deficiency anemia and Giardia infection. A case-control study concerning the effect of giardiasis on serological levels of iron among G. intestinalisinfected children aged two to 14 years-old in Turkey concluded that iron levels were lower in children with giardiasis, due to malabsorption ${ }^{18}$. A recent study in Spain reported a significantly lower level of serum iron and ferritin in patients with and without giardiasis as a result of damage to the intestinal mucosa ${ }^{30}$. Moreover, in rural Ecuadorian children, $G$. intestinalis infection had an adverse impact on children's linear growth and hemoglobin concentration ${ }^{42}$. However, in this study, no association was determined with iron deficiency anemia or ferritin deficiency in children with Giardia infection. These results are in agreement with a study involving patients with asymptomatic giardiasis, showing only with cyst excretion, in which intestinal absorption of iron and the hemoglobin response to oral iron therapy in iron-deficient anemic children were not affected ${ }^{15}$. The results presented here cannot be reliably compared with the study cited, because some of our patients showed clinical symptoms $(21.2 \%)$ and trophozoite excretion was observed.
Given the high prevalence of asymptomatic Giardia infection (78.8 $\%$ ) in the present study population, underling chronic parasitic infection as a contributing cause to poor nutritional status and subsequent reduced weight-for-age and weight-for-height cannot be ruled out. In light of these results, further investigation is needed to examine the association between asymptomatic Giardia infection and underweight and wasting among children participating in the complementary nutrition program in Antioquia, Colombia.

The ability to determine the true nutritional status of the population is limited by the use of a cross-sectional study design. A longitudinal study would permit visualization of the changes in weight, height and growth over time, which are better indicators of malnutrition patterns.

The present findings do not provide evidence that Giardia infection is the causal factor of stunting among the children in this study. However, it is very probable that infection is one of several factors associated with low nutritional status, together with sanitary and socioeconomic conditions.

In conclusion, the study demonstrates the importance of Giardia infection as a predictor of stunting in the complementary nutrition program for children from Antioquia, Colombia. These findings are of great importance and should be considered when designing health education programs or interventions to target childhood linear growth failure in complementary nutrition programs for children. Addressing these sociodemographic factors are a means of preventing future growth impairment, as well as the impairment of the physical and mental development in children, and will assist in alleviating malnutrition and improving the quality of health of children at risk.

Conflicts of interest statement: The authors have no conflicts of interest concerning the work reported in this paper.

\section{RESUMO}

\section{Giardia intestinalis e estado nutricional em crianças participantes do programa de nutrição complementar, melhoramento alimentar e nutricional da Antioquia (MANA) - Instituto Colombiano de Bem-Estar Familiar (ICBF), Antióquia, Colombia, maio a outubro de 2006}

A infecção pela Giardia intestinalis está amplamente distribuída no mundo apresentando a maior prevalência nos países em desenvolvimento. Em crianças, esta parasitose pode ter consequiências graves no estado geral de saúde assim como no ganho de peso e estatura. O objetivo desta pesquisa foi estabelecer a associação entre a infecção com Giardia e o estado nutricional das crianças beneficiárias do programa de complementação alimentar - MANA. Um estudo de corte no qual foram avaliadas 2035 crianças entre os oito meses e os seis anos de idade foi realizado. A informação foi obtida a partir de questionários estruturados, medições antropométricas e exame de fezes. Os resultados mostraram que $27,6 \%$ das crianças estavam infectadas com Giardia intestinalis, das quais $8,1 \%$ apresentaram desnutrição moderada, $1,9 \%$ desnutrição grave e 14,1\% franca queda no crescimento. Em conclusão, nesta população a Giardíase foi indicador de desnutrição grave. 
BOTERO-GARCÉS, J.H.; GARCÍA-MONTOYA, G.M.; GRISALES-PATIÑO, D.; AGUIRRE-ACEVEDO, D.C. \& ÁLVAREZ-URIBE, M.C. - Giardia intestinalis and nutritional status in children participating in the complementary nutrition program, Antioquia, Colombia, May to October 2006. Rev. Inst. Med. trop. S. Paulo, 51(3): 155-162, 2009.

\section{ACKNOWLEDGMENTS}

This study was supported by the Gobernación de Antioquia, Dirección Seccional de Salud de Antioquia, Project Grant CI148-2005. The authors would like to thank the Gerencia Plan Departamental de Seguridad Alimentaria y Nutricional de Antioquia-MANÁ and Instituto Nacional de Salud-Colombia. The authors are very grateful to the heads and employees of local hospitals, children's families and the community for their help, hospitality and cooperation. In addition, the authors thank Lina Mabel Vélez for her support in data processing and management.

\section{REFERENCES}

1. AHMED, M.M. \& el HADY, H.M. - A preliminary survey of parasitic infections and nutritional status among school children in Riyadh, Saudi Arabia. J. Egypt. Soc. Parasit., 19: 101-105. 1989.

2. ALI, S.A. \& HILL, D.R. - Giardia intestinalis. Curr. Opin. infect. Dis., 16: 453-460, 2003.

3. AL-MEKHIAFI, M.S.; AZLIN, M.; NOR AINI, U. et al. - Giardiasis as a predictor of childhood malnutrition in Orang Asli children in Malaysia. Trans. roy. Soc. trop. Med. Hyg., 99: 686-691, 2005.

4. ALVARADO, B.E. \& VÁSQUEZ, L.R. - Determinantes sociales, practicas de alimentación y consecuencias nutricionales del parasitismo intestinal en niños. Biomédica, 26: 82-94, 2006.

5. ASTIAZARÁN-GARCÍA, H.; ESPINOSA-CANTELLANO, M.; CASTAÑÓN, G.; CHÁVEZ-MUNGUÍA, B. \& MARTÍNEZ-PALOMO, A. - Giardia lamblia: effect of infection with symptomatic and asymptomatic isolates on the growth of gerbils (Meriones unguiculatus). Exp. Parasit., 95: 128-135, 2000.

6. AWASTHI, S. \& PANDE, V.K. - Prevalence of malnutrition and intestinal parasites in preschool slum children in Lucknow. Indian Pediat., 34: 599-605, 1997.

7. BARTLETT, A.V.; ENGLENDER, S.J.; JARVIS, B.A. et al. - Controlled trial of Giardia lamblia: control strategies in day care centers. Amer. J. publ. Hlth, 81: 1001-1006, 1991.

8. BAUMAN, D.E. \& CURRIE, W.B. - Partitioning of nutrients during pregnancy and lactation: a review of mechanisms involving homeostasis and homeorhesis. J. Dairy Sci., 63: 1514-1529, 1980.

9. CARVALHO-COSTA, F.A.; GONÇALVES, A.Q.; LASSANCE, S.L. et al.- Giardia lamblia and other intestinal parasitic infections and their relationships with nutritional status in children in Brazilian Amazon. Rev. Inst. Med. trop. S. Paulo, 49: 147-153, 2007.

10. CELIKSÖZ, A.; ACIÖZ, M.; DEGERLI, S. et al. - Effects of giardiasis on school success, weight and height indices of primary school children in Turkey. Pediat. Int., 47: $567-571,2005$.

11. CHANG, S.M.; WALKER, S.P.; GRANTHAM-McGREGOR, S. \& POWELL, C.A. - Early childhood stunting and later behaviour and school achievement. J. Child Psychol., 43: 775-783, 2002.

12. CORDINGLEY, F.T. \& CRAWFORD, G.P. - Giardia infection causes vitamin B12 deficiency. Aust. N. Z. J. Med., 16: 78-79, 1986.

13. CORREDOR, A.; ARCINIEGAS, E. \& HERNÁNDEZ, C.A. - Parasitismo intestinal. Bogotá, Ministerio de Salud; Instituto Nacional de Salud Colombia, 2002.

14. CRAUN, G.F. - Waterborne giardiasis in the United States: a review. Amer. J. publ. HIth, 69: 817-819, 1979.
15. DE MORAIS, M.B.; SUZUKI, H.U.; CORRAL, J.N.; MACHADO, N.L. \& NETO, U.F. - Asymptomatic giardiasis does not affect iron absorption in children with iron deficiency anemia. J. Amer. Coll. Nutr., 15: 434-438, 1996.

16. DE ONIS, M.; MONTEIRO, C.; AKRE, J. \& GLUGSTON, G. - The worldwide magnitude of protein-energy malnutrition: an overview from the WHO Global Database on Child Growth. Bull. Wld Hlth Org., 71: 703-712, 1993.

17. DE SOUZA, E.; DA SILVA-NUNES, M.; MALAFRONTE, R.S. et al. - Prevalence and spatial distribution of intestinal parasitic infections in a rural Amazonian settlement, Acre State, Brazil. Cadern. Saúde públ. (Rio de J.), 23: 427-434. 2007.

18. ERTAN, P.; YERELI, K.; KURT, O.; BALCIOGLU, I.C. \& ONAG, A. - Serological levels of zinc, copper and iron elements among Giardia lamblia infected children in Turkey. Pediat. Int., 44: 286-288, 2002.

19. GENDREL, D.; TRELUYER, J.M. \& RICHARD-LENOBLE, D. - Parasitic diarrhea in normal and malnourished children. Fundam. clin. Pharmacol., 17: 189-197, 2003.

20. GIBSON, R.S. - Principles of nutritional assessment. New York, Oxford University Press, 1990

21. GIRALDO-GOMEZ, J.M.; LORA, F.; HENAO, L.H.; MEJÍA, S. \& GÓMEZ-MARIN, J.E. - Prevalencia de giardiasis y parasites intestinales en niños preescolares de hogares que son atendidos como parte del programa estatal en Armenia, Colombia. Rev. Salud públ. (Bogotá), 7: 327-338, 2005

22. GUIMARÃES, S. \& SOGAYAR, M.I. - Occurrence of Giardia lamblia in children of municipal day-care centers from Botucatu, São Paulo State, Brazil. Rev. Inst. Med. trop. S. Paulo, 37: 501-506, 1995.

23. HESHAM, M.S.; EDARIAH, A.B. \& NORHAYATI, M. - Intestinal parasitic infections and micronutrient deficiency: a review. Med. J. Malaysia, 59: 284-293, 2004.

24. IANNACONE, J.; BENÍTEZ, M.J. \& CHIRINOS, L. - Prevalencia de infección por parásitos intestinales en escolares de primaria de Santiago de Surco, Lima, Perú. Parasit. latinoamer., 61: 54-62, 2006.

25. KENT, G.P.; GREENSPAN, J.R.; HERNDON, J.L. et al. - Epidemic giardiasis caused by a contaminated public water supply. Amer. J. publ. Hlth, 78: 139-143, 1988.

26. LOEWENSON, R.; MASON, P.R. \& PATTERSON, B.A. - Giardiasis and the nutritional status of Zimbabwean schoolchildren. Ann. trop. Paediat., 6: 73-78, 1986.

27. LORA-SUAREZ, F.; MARIN-VASQUEZ, C.; LOANGO, N. et al. - Giardiasis in children living in post-earthquake camps from Armenia (Colombia). BMC. Publ. Hlth, 2: 5, 2002.

28. MINVIELLE, M.; PEZANNI, B.; CORDOBA, M.A. et al. - Epidemiological survey of Giardia spp. and Blastocystis hominis in an Argentinian rural community. Korean J. Parasit., 42: 121-127, 2004

29. MUNIZ-JUNQUEIRA, M.I. \& QUEIROZ, E.F. - Relationship between protein-energy malnutrition, vitamin A, and parasitoses in living in Brasilia. Rev. Soc. bras. Med. trop., 35: 133-141, 2002

30. OLIVARES, J.L.; FERNÁNDEZ, R.; FLETA, J. et al. - Iron defiency in children with Giardia lamblia and Enterobius vermicularis. Nutr. Res., 24: 1-5, 2004.

31. ORGANIZACIÓN MUNDIAL DE LA SALUD - Medición del cambio del estado nutricional. Ginebra, Organización Mundial de la Salud, 1983. p. 12-28.

32. ORGANIZACIÓN MUNDIAL DE LA SALUD - El estado físico: uso e interpretación de la antropometría. Ginebra, Organización Mundial de la Salud, 1995. p. 45139.

33. PEREIRA, M.G.; ATWILL, E.R. \& BARBOSA, A.P. - Prevalence and associated risk factors for Giardia lamblia infection among children hospitalized for diarrhea in Goiania, Goias State, Brazil. Rev. Inst. Med. trop. S. Paulo, 49: 139-145, 2007. 
BOTERO-GARCÉS, J.H.; GARCÍA-MONTOYA, G.M.; GRISALES-PATIÑO, D.; AGUIRRE-ACEVEDO, D.C. \& ÁLVAREZ-URIBE, M.C. - Giardia intestinalis and nutritional status in children participating in the complementary nutrition program, Antioquia, Colombia, May to October 2006. Rev. Inst. Med. trop. S. Paulo, 51(3): 155-162, 2009.

34. PETTOELLO-MANTOVANI, M.; GUANDALINI, S.; ECUBA. P.; CORVINO, C. \& Di MARTINO, L. - Lactose malabsorption in children with symptomatic Giardia lamblia infection: feasibility of yogurt supplementation. J. Pediat. Gastroent. Nutr., 9: 295-300, 1989

35. QUIHUI-COTA, L.; VALENCIA, M.E.; CROMPTON, D.W. et al. - Prevalence and intensity of intestinal parasitic infections in relation to nutritional status in Mexican schoolchildren. Trans. roy. Soc. trop. Med. Hyg., 98: 653-659, 2004.

36. REYNOLDSON, J.A.; BEHNKE, J.M.; GRACEY, M. et al. - Efficacy of albendazole against Giardia and hookworm in a remote Aboriginal community in the north of Western Australia. Acta trop., 71: 27-44, 1998.

37. RINNE, S.; RODAS, E.J.; GALER-UNTI, R.; GLICKMAN, N. \& GLICKMAN, L.T. Prevalence and risk factors for protozoan and nematode infections among children in an Ecuadorian highland community. Trans. roy. Soc. trop. Med. Hyg., 99: 585-592, 2005 .

38. RÍOS, Y.L.G. - Prevalencia de giardiasis en preescolares de 4-6 años, Unidades Educativas, El Alto La Paz, segundo semestre 2003: julio-octubre 2003. La Paz, 2003. (MSc thesis - Facultad de Medicina Universidad Mayor de San Andrés).

39. RITCHIE, LS. - An ether sedimentation technique for routine stool examinations. Bull. U. S. Army med. Dept., 8: 326, 1948.

40. RODRÍGUES, M.A.; DE-CARVALHO, M.F. \& MONTENEGRO, M.R. - Effects of protein deficiency and natural intestinal infection with Giardia lamblia on jejunal intraepithelial lymphocytes in rats of different ages. Braz. J. med. Biol. Res., 27: 1347-1353, 1994

41. ROSE, J.B.; HAAS, C.N. \& REGLI S. - Risk assessment and control of waterborne giardiasis. Amer. J. publ. Hlth, 81: 709-713, 1991.

42. SACKEY, M.E.; WEIGEL, M.M. \& ARMIJOS, R.X. - Predictors and nutritional consequences of intestinal parasitic infections in rural Ecuadorian children. J. trop. Pediat., 49: 17-23, 2003.

43. SAVIOLI, L.; BUNDY, D. \& TOMKINS, A. - Intestinal parasitic infections: a soluble public health problem. Trans. roy. Soc. trop. Med. Hyg., 86: 353-354, 1992.

44. SAVIOLI, L.; SMITH, H. \& THOMPSON, A. - Giardia and Cryptosporidium join the "Neglected Diseases Initiative". Trends Parasit., 22: 203-208, 2006.

45. SCHROEDER, D.G. \& BROWN, K.H. - Nutritional status as a predictor of child survival: summarizing the association and quantifying its global impact. Bull. Wld Hlth Org., 72: $569-579,1994$.
46. SEREEBUTRA, P.; SOLOMONS, N.; ALIYU, M.H. \& JOLLY, P.E. -Sociodemographic and environmental predictors of childhood stunting in rural Guatemala. Nutr. Res., 26: $65-70,2006$

47. SPRINGER, S.C. \& KEY, J.D. - Vitamin B12 deficiency and subclinical infection with Giardia lamblia in an adolescent with agammaglobulinemia of Bruton. J. Adolesc. Hlth, 20: 58-61, 1997.

48. SOLOMONS, N.W. - Giardiasis: nutritional implications. Rev. infect. Dis., 4: 859-869, 1982

49. STEPHENSON, L.S.; CROMPTON, D.W.; LATHAM, M.C. et al. - Relationships between Ascaris infection and growth of malnourished preschool children in Kenya. Amer. J. clin. Nutr., 33: 1165-1172, 1980

50. STEPHENSON, L.S.; POND, W.G.; NESHEIM, M.C.; KROOK, L.P. \& CROMPTON D.W. - Ascaris suum: nutrient absorption, growth, and intestinal pathology in young pigs experimentally infected with 15-day-old larvae. Exp. Parasit., 49: 15-25, 1980

51. TELLEZ, A.; MORALES, W.; RIVERA, T. et al. - Prevalence of intestinal parasites in the human population of Leon, Nicaragua. Acta trop., 66: 119-125, 1997.

52. THOMPSON, R.C. - Giardiasis as a re-emerging infectious disease and its zoonotic potential. Int. J. Parasit., 30: 1259-1267, 2000.

53. WILSON, W.M.; DUFOUR, D.L.; STATEN, L.K. et al. - Gastrointestinal parasitic infection, anthropometrics, nutritional status, and physical work capacity in Colombian boys. Amer. J. hum. Biol., 11: 763-771, 1999.

54. WONGJINDANON, N.; SUKSRICHAVALIT, T.; SUBSUTTI, W. et al. - Current infection rate of Giardia lamblia in two provinces of Thailand. Southeast Asian J. trop. Med. publ. HIth, 36: 21-25, 2005.

55. WORLD HEALTH ORGANIZATION - Iron deficiency anaemia assessment, prevention and control. A guide for programme managers. Geneva, World Health Organization, 2001. p. 33-43.

56. YONG, T.; SIM, S.; LEE, J. et al. - A small-scale survey on the status of intestinal parasite infections in rural villages in Nepal. Korean J. Parasit., 38: 275-277, 2000.

Received: 1 April 2008

Accepted: 26 February 2009 